\title{
Health advocacy in nursing: contribution to the reorientation of the Brazilian healthcare model
}

\author{
Advocacia em enfermagem: contribuição para a reorientação do modelo assistencial no Brasil
}

Defensa de la salud en enfermería: la contribución para la reorientación del modelo asistencial en Brasil

\section{Maria Amélia de Campos Oliveira', Tharsila Martins Rios da Silva' \\ ' Universidade de São Paulo, School of Nursing. São Paulo, Brazil.}

\section{How to cite this article:}

Oliveira MAC, Silva TMR. Health advocacy in nursing: contribution to the reorientation of the Brazilian healthcare model. Rev Bras Enferm [Internet]. 2018;71(Suppl 1):700-3. [Thematic Issue: Contributions and challenges of nursing practices in collective health] DOI: http://dx.doi.org/10.1590/0034-7167-2017-0615

\section{Submission: 09-14-2017 Approval: 10-16-2017}

\begin{abstract}
Inequalities are the result of the different positions held by individuals in different social spaces, and are related to the distribution of power and property. Health advocacy is a strategy to reduce such inequalities, especially those considered unfair and unnecessary, aiming to fully promote the right to health. This study aims to discuss the contribution of nursing in the field of health advocacy, which includes the right of everyone to a healthy life as one of the strategies for the reorientation of the Brazilian healthcare model.
\end{abstract}

Descriptors: Health Advocacy; Nursing; Health Services; Health Inequalities; Human Rights.

\section{RESUMO}

As desigualdades são resultado das distintas posições ocupadas pelos indivíduos em diferentes espaços sociais; e são relacionadas à repartição de poder e propriedade. A advocacia em saúde é uma estratégia para a redução de tais desigualdades, principalmente as consideradas injustas e desnecessárias, com vistas ao alcance pleno do direito à saúde. O presente estudo pretende discutir a contribuição da Enfermagem no campo da advocacia em saúde, no qual se inclui o direito de todos a uma vida saudável, como uma das estratégias para reorientação do modelo assistencial no Brasil.

Descritores: Advocacia em Saúde; Enfermagem; Serviços de Saúde; Desigualdades em Saúde; Direitos Humanos.

\section{RESUMEN}

Las desigualdades son el resultado de las distintas posiciones ocupadas por los individuos en distintos espacios sociales; y son relacionadas a la repartición de poder y de propiedad. La defensa de la salud es una estrategia para la reducción de tales desigualdades, principalmente, las consideradas injustas y desnecesarias. Con el objetivo del alcance pleno del derecho a la salud, el presente estudio pretende discutir la contribución de la Enfermería en el campo de la defensa de la salud, en el cual se incluye el derecho de todos a una vida saludable, como una de las estrategias para reorientación del modelo asistencial en Brasil.

Descriptores: Defensa de la Salud; Enfermería; Servicios de Salud; Desigualdades en la Salud; Derechos Humanos. 


\section{INTRODUCTION}

The contribution of nursing to renovate the Brazilian healthcare model is expressive. Possibly, it is the most substantive among healthcare providers, given the massive presence of nurses and other members of the nursing staff at all levels of care of the Brazilian Unified Health System (SUS), especially in primary health care, in which their performance is widespread in thousands of health teams throughout the country. Even where there are no doctors and other health professionals, there are nurses, technicians, and assistants; and not provisionally, until they get another position, but permanently and continuously, taking care of families, social groups, and communities, especially the most vulnerable ones, which solely rely on the public services provided by SUS.

Extended care and accountability for individuals, social groups, families, and communities in an included territory are some of the tasks envisaged for primary health care nursing professionals, described in the National Policy of Primary Health Care (PNAB - Política Nacional de Atenção Básica) ${ }^{(1)}$. This policy is guided by the principles of comprehensiveness and equity to meet the health needs of the registered population, aiming to promote their full access to health ${ }^{(1)}$.

The right to health is an inalienable right enacted by the Brazilian Federal Constitution of 1988. However, this right is not fully ensured, so that not everyone have the same opportunities to access technologies capable of improving health and prolonging life, because of inequities in the mode of production and the lack of access to decent living conditions ${ }^{(2)}$.

Health inequities are based on the social determination of the health-disease process and on the political and economic influences of a society. Besides being products of social determination, such inequities also affect the organization of healthcare systems, impacting the right to health in $\mathrm{Brazi}^{(2)}$.

This article seeks to situate the contribution of nursing to the field of health advocacy, especially regarding human rights, which include the right of everyone to a healthy life. It aims to bring subsidies for the defense of the right to health as part of a strategy for reorientation of the Brazilian healthcare model and for fighting health inequities.

\section{HEALTH INEQUITIES}

The term "inequity" is widely used in the field of health. Besides being found in discussions on the distribution of financial resources in the area and on access to services, it is also often used to explain the health of individuals and groups as a product of social organization ${ }^{(3-4)}$.

It is known that social, economic, and cultural conditions affect the health of different population groups and reflect inequities generated by society ${ }^{(4)}$.

The term "inequity" is based on a broad and generic concept, used in the field of human rights, to describe differences between individuals or social groups that cannot be prevented or helped. When they can be prevented and result in situations of illness or vulnerability, they are considered unfair and have to be overcome ${ }^{(3)}$.
Situations of social disadvantage caused by unfair inequities increase the vulnerability of people and social groups to processes of wear and illness ${ }^{(3-4)}$. In cases of persistent injustice, the vulnerability of people and social groups can be severely exacerbated. The persistence of situations of social exclusion, poverty, difficult access to goods and products, or loss of the opportunities to have a decent life reinforces injustice and health inequalities ${ }^{(3-4)}$.

Health inequalities are avoidable and reducible forms of injustice, linked to different situations of life in society ${ }^{(3)}$. They are related to lack of freedom of choice, exposure to stressful living conditions, lack of access to essential services, and changes in the social position linked to health conditions ${ }^{(3)}$. These are inequities that, depending on the social context, take on features of exclusion and injustice that can be overcome or reduced, but are not ${ }^{(3-4)}$. Health advocacy can be a strategy for overcoming them.

\section{HEALTH ADVOCACY}

The term "advocacy" is related to the claim of a right. Health advocacy can therefore be understood as the set of actions that seek to claim rights for the health of individuals and social groups, especially the disadvantaged ones ${ }^{(5-6)}$.

The concept of health advocacy is part of a theory based on the idea of defense against health inequities. The term is related to the construction of actions and policies aimed at reducing such iniquities, which are characterized by life conditions related to the unequal distribution of power, income, and resources among countries, social groups, and individuals ${ }^{(5-6)}$.

It can be a powerful initiative to promote the improvement of living and health conditions, but it requires, from health professionals, an action guided by the principles of justice and equity ${ }^{(5-6)}$. Its purpose is to defend and protect the health rights of people and social groups at a disadvantage, as well as to help them get health care by empowerment ${ }^{(5-7)}$.

When searching, in the literature, health advocacy practices for overcoming or minimizing health iniquities, Farrer et al. ${ }^{(5)}$ identified six dimensions of advocacy that contribute to promote health equity: 1) producing types of evidence needed to defend the equity in health and ways to transfer this knowledge to other political processes; 2) highlighting the importance of the participation of the various subjects in defense of health equity; 3) conveying health messages to society, as a value and a form of social justice, right of individuals, and state liability; 4) adapting arguments to different political views; 5) identifying barriers and facilitators of the effective defense for health equity; 6) instituting practices and activities that increase the effectiveness of health advocacy.

A literature review found different definitions for the term "advocacy" in the field of public health. It also identified that few publications on this topic refer to the principles of equity and social justice as the main goal of health advocacy in favor of socially disadvantaged groups. Its authors classified advocacy according to the type of action carried out: 1) actions on a given particular cause to protect or promote the health of a given population or social groups; 2) actions to strengthen 
the capacity of people to act autonomously to improve their own health; 3) actions intended to reduce structural barriers to health; and, finally, 4) actions that use the media to exert influence on public policy initiatives ${ }^{(6)}$.

The main structural barriers related to the protection of public health are related to the biomedical nature of the hegemonic model of health care; to the little argumentation using the concepts of social determination and social inequities in health for the defense of the right to health; to the little involvement of professionals to defend public health; to the little political will; to the low intersectoral involvement; and to the lack of independence of some health sectors for public health advocacy ${ }^{(6)}$.

The Brazilian health care reform can be considered an action of health advocacy, because it sought to reduce social inequities and change the structure of the healthcare model. But, still, the biggest challenge for the implementation of the right to health in Brazil is in developing health democracy, which is related to the effective participation of society in strategic decision-making processes that aim to ensure the universal, egalitarian, and integral right to health ${ }^{(8)}$. The use of the media for the protection of public health, including digital tools, makes it possible to expand the social mobilization in defense of health.

\section{ADVOCACY AND NURSING}

Discussions on advocacy in the nursing field began around the 1970s, from social movements that claimed more autonomy for people in health care before the practices of paternalistic care in force then ${ }^{(7,9)}$. Such movements, seeking to direct the decision-making power of health care to the patients themselves, provoked discussions on the role of nurses as defenders of those rights, since, for being close to the patients, they would be better suited for working with the concept of empowerment ${ }^{(9)}$.

In 1976, the American Nurses Association (ANA) recognized advocacy as inherent to the professional practice of nursing. The term gained greater emphasis in the 1980s in discussions on the work process of nurses, on their longer stay at health services - compared to other professionals -, and on the proximity to patients ${ }^{(9)}$.
Although the concept of advocacy is not clearly defined in nursing, its exercise is related to: providing the required subsidies for individuals and social groups to access health; defending the rights of these people by the quality of care; and acting as a link between individuals or groups and health services ${ }^{(7)}$.

Health advocacy represents a key element for ethics in nursing, since it considers that respecting human rights, life, and human dignity is inherent to the professional practice of nursing ${ }^{(10)}$. In addition, as well as other healthcare professionals, nurses have an ethical obligation of defending individuals and vulnerable families in different contexts and in hierarchical health systems, because advocacy recognizes that both individuals and families, when occupying certain positions in society, need someone to defend them when they are not able to speak for themselves or when their voices are not heard.

In addition to being an ethical imperative in the field of nursing, actions on the social determination of health can be considered a way to achieve equity in health. Health advocacy is also important to achieve social justice. Public health actions involving the defense of equity also favor the autonomy of social groups.

Nurses can act in different ways in the defense of individuals, families, and vulnerable social groups in SUS. Certainly, it is expected that they ensure appropriate and consistent health care and help the access of patients to health services. They may also engage in research that produce evidence for changes in healthcare practices; act in favor of revision of health policies, to develop policies sensitive to the needs of patients; or enter the political arena to promote health equity ${ }^{(9)}$.

Equity and social justice are the main goal of health advocacy on behalf of socially disadvantaged groups. Actions on the social conditions that produce health results are important means to achieve equity, as well as an ethical imperative in the field of nursing(6).

The reorientation of the healthcare model is part of the commitment of nursing to the advocacy for health equity. It overcomes, in the dialectical sense of the term, the individual or microsocial dimension of the nurse-patient relationship in which nurses usually work, and advances toward social justice. The structural organization of the health system is certainly not the only action to reduce social inequities. Primary health care has a key role in the achievement of this goal, especially for socially disadvantaged groups.

\section{REFERENCES}

1. Brasil. Ministério da Saúde. Portaria $n^{\circ}$ 2.488, de 21 de outubro de 2011. Aprova a Política Nacional de Atenção Básica, estabelecendo a revisão de diretrizes e normas para a organização da Atenção Básica, para a Estratégia Saúde da Família (ESF) e o Programa de Agentes Comunitários de Saúde (PACS). Diário Oficial da União, 2011 out. 24. Seção 1, p.55.

2. d'Ávila LS, Saliba GR. A efetivação do direito à saúde e sua interface com a justiça social. Rev Direito Sanit [Internet]. 2017 [cited 2017 Jul 10];17(3):15-38. Available from: https://www.revistas.usp.br/rdisan/article/view/127772/124770

3. Starfield B. The hidden inequity in health care. Int J Equity Health [Internet]. 2011 [cited 2016 Dec 5];10(15):1-3. Available from: https://equityhealthj.biomedcentral.com/track/pdf/10.1186/1475-9276-10-15?site = equityhealthj.biomedcentral.com

4. Fiorati RC, Arcêncio RA, Souza LB. Social Inequalities and access to health: challenges for society and the nursing field. Rev Latino-Am Enferm [Internet]. 2016 [cited 2016 Dec 5];24: e2687. Available from http://www.scielo.br/pdf/rlae/v24/es_0104-1169rlae-24-02687.pdf 
5. Farrer L, Marinetti C, Cavaco YK, Costongs C. Advocacy for health equity: a synthesis review. Milbank Q [Internet]. 2015 [cited 2017 Jul 10];93(2):392-437. Available from: http://onlinelibrary.wiley.com/doi/10.1111/1468-0009.12112/epdf

6. Cohen BE, Marshall SG. Does public health advocacy seek to redress health inequities? a scoping review. Health Soc Care Commun[Internet]. 2017 [cited 2017 Jul 5];25(2):309-28. Available from: http://onlinelibrary.wiley.com/doi/10.1111/hsc.12320/ epdf

7. Barlem JGT, Lunardi VL, Barlem ELD, Ramo AM, Figueira AB, Fornari NC. Nursing beliefs and actions in exercising patient advocacy in a hospital context. Rev Esc Enferm USP [Internet]. 2015 [cited 2016 Dec 5];49(5):806-12. Available from: http://www. scielo.br/pdf/reeusp/v49n5/0080-6234-reeusp-49-05-0811.pdf

8. Aith FMA. Direito à saúde e democracia sanitária: experiências brasileiras. Rev Direito Sanit [Internet]. 2015 [cited 2016 Nov 15];15(3):85-90. Available from: http://www.revistas.usp.br/rdisan/article/view/97328/96340

9. Bu X, Wu YB. Development and psychometric evaluation of the instrument: attitude toward patient advocacy. Res Nurs Health [Internet]. 2008 [cited 2016 Dec 10];31(1):63-75. Available from: http://onlinelibrary.wiley.com/doi/10.1002/nur.20233/epdf

10. Ventura CAA, Mello DF, Andrade RD, Mendes IAC. Aliança da enfermagem com o usuário na defesa do SUS. Rev Bras Enferm [Internet]. 2012 [cited 2016 Dec 10];65(6):893-8. Available from: http://www.redalyc.org/pdf/2670/267025361003.pdf 